\title{
The consequences of armed conflicts on life paths of Bosniaks from Eastern Bosnia
}

\author{
Ana Uher*, Vladimír Ira
}

Institute of Geography of the Slovak Academy of Sciences, Slovakia

* Corresponding author: geoguher@savba.sk

\begin{abstract}
This article sets out to describe the individual mobility of persons affected by the war in former Yugoslavia from a long-term, biographical perspective. It evaluates how the conflict and post-conflict conditions limit or enhance the spatial range of individual activities. The time-geographical approach is applied through the usage of spatio-temporal records of the war and post-war life. Thirty-two respondents from Bosnia and Herzegovina were interviewed, and asked to generate an "ex-post facto" open time-space activity diary. The article demonstrates the usefulness of the time-space activity diary usage as a significant instrument for a sensible analysis of life-paths.
\end{abstract}

\section{KEYWORDS}

life paths; time-geography; time-space activity diaries; biographies; war conflict; post-war situation; Eastern Bosnia and Herzegovina

Received: 29 March 2019

Accepted: 31 December 2020

Published online: 18 March 2021

Uher, A., Ira, V. (2021): The consequences of armed conflicts on life paths of Bosniaks from Eastern Bosnia.

AUC Geographica 56(1), 95-107

https://doi.org/10.14712/23361980.2021.4

(C) 2021 The Authors. This is an open-access article distributed under the terms of the Creative Commons Attribution License (http://creativecommons.org/licenses/by/4.0). 


\section{Introduction}

Every war and armed conflict in the history was accompanied by inhuman treatment, violence, atrocities and killings, which imprints deep mark on all members of the society regardless of their gender, age, education, cultural background, nationality or religious membership. War kills and its consequences go beyond its end and are profound for future development. The breakup of Yugoslavia in the nineties of the 20th century was not an exception.

Violence and wars did not have impact only on the economy but also on social structures within the territory of former Yugoslavia. It also affected the large migratory movements that emerged towards the end of the 20th century. Armed conflicts lead to forced migration and long-term refugee problems. As Ljuboja (2015) mentioned, relocations caused by violence and wars or displacements of citizens belonging to different ethnic or religious groups by the state authorities certainly represent the biggest and the most obvious movements of people in relatively short periods of time. Significant changes, caused by the conflicts at the end of the last century, occurred in the inner structure of the populations of Croatia, Bosnia and Herzegovina and Serbia. They represent the most recent examples that have remained etched in the collective memory of the nations in question.

In the eyes of the outside observers the Yugoslav social model has been a relatively successful symbiosis of different cultures and traditions, but the period of extreme political tensions, growth of nationalist forces and escalating national conflicts in a number of the republics in the late 1980s, culminated into several wars in the early 1990s. The beginning of the 1990s pointed to the future development of events. Most of the republics, Slovenia, Croatia, Bosnia and Herzegovina and Macedonia proclaimed independence after the dissolution of Yugoslavia in early 1992.

Despite the centuries of the co-existence within the multicultural society, Bosnia and Herzegovina experienced a bitter transition from the communist era to independence. The war from 1992 to 1995 in Bosnia and Herzegovina resulted in huge direct and indirect demographic changes in this former Yugoslav republic. The initial period of the post-war recovery was characterized by a massive devastation, dislocations and deaths. Nowadays post-war Bosna and Herzegovina consists of two entities based on its constitutional and administrative structure: the Federation of Bosnia and Herzegovina (FBiH) and Republika Srpska (RS) and Brčko District (self-governing administrative unit).

In order to understand and explain armed conflicts, the breakdown of the state and post-conflict development and to place these events in a theoretical plain, the wide range of theories tends to describe inter alia the issues of ethnicity, nation, nationality, interactive processes between events and personal motives for expressing intolerance, as far as conflicts, violence, ethnic cleansing, and other (e.g. Horowitz 1985; Kaplan 1994; Connor 1994; Hutchinson, Smith 1996; Collier 2000; Sekulić et al. 2002; Collier, Hoeffler 2004; Blagojević 2009; Beširević 2010; Jesse and Williams 2011). Societies in the post-conflict time (as it was in some former republics of Yugoslavia) and the processes of renewal and development on almost all of its levels are also becoming the subject of special researchers' interest (Blagojević 2004; Lambourne 2004). In connection with the studied issues, the theories focused on the migration (Drbohlav, Uherek 2007) and its determinants (e.g. Drbohlav 2011) are also important. Victims of civil war and forced displacement in former Yugoslavia constitute an important form of forced migration. Forced migration is the result of a string of connected emergencies and is an integral part of international (regional) relationships and societal crises (Castles 2003).

All significant human interactions in the conflict and post-conflict societies can be seen from the geographical (time-space perspectives), especially from the behavioural geography and time-geography point of view. Behavioural geography studies human spacetime activities as the outcome of decisions made by individuals within the constraints set by the society and the environment and according to their perception and understanding of the situation. Behavioural geography is not based on an abstract model of rational behaviour, but is focused on what people do and why they do it (Castree et al. 2013). Behavioural approach in geography recognizes that people live simultaneously in a subjective environment of values, meanings and perceptions and in an objective physical environment. Current behavioural geographical approaches include both, qualitative and quantitative methods (Golledge, Stimson 1990; Golledge 2008; Gold 2009). Behavioural geography was also critically used to study individuals' space-time actions, in choosing whether to stay or to move, along with their perceptions of extreme events (conflicts). Behavioural geography continued to expand into various areas including potential and real ethnic and religious tensions and war conflicts and tensions (e.g. Ira 1997; Jacobson 2006; Uher 2018; Uher, Ira 2019). Many life stories of the 20th and 21st century in the areas affected by the war conflict have similar mixtures of individual lives, network building and the intervention of authorities. But the lack of information, specific social and family life relations existing in certain time and in certain cultural conditions can be considered as a factor influencing their social and spatial mobility. Time geography, as outlined first by Torsten Hägerstrand, is an approach aimed at the clarification of the constraints to objects and individuals in their search for slots in the time-space continuum. Hägerstrand (1970) builds on everyday experience and the bounding capacity of time and space. Every individual follows a trajectory (observed paths) in 
time-space. Time-geography studies a broad spectrum of own concepts (Ellegård 1999 and 2019; Lenntorp 1999; Ira 2001; Lundén 2003; Schwanen 2009; Schwanen, Kwan 2012). The individual human being is an integer unit of existence. The life paths of individuals are influenced by biological needs and by societal factors, among other political regulations (Kleinepier et al. 2015). The life trajectory of a person whose demands do not comply with the political environment will search for refuge domain, either as a permanent solution in full or partial accord with her or his demands, or as a stepping-stone in the search for full satisfaction. Planning his or her day, year and life, the individual has to utilize and accommodate to all the networks and structures available (Lundén 2003).

The aim of this article is to analyse how the complex and often changeable and unpredictable conditions surrounding thirty two individuals from Eastern Bosnia, who were affected by war, limit or enhance their range of activities in the conflict and post-conflict space and how they are manifested in their life-paths formed by their time-space behavioural patterns. The paper gradually introduces brief theoretical and methodological framework, the studied area with its short history and the data and methods used. Furthermore, the results of spatio-temporal research of life paths conducted among selected sample of Bosniaks are presented, followed by a discussion and conclusion.

\section{Material and methods}

\subsection{Study area}

Our research, applying a time-geographical approach using spatio-temporal records of a rich complexity of

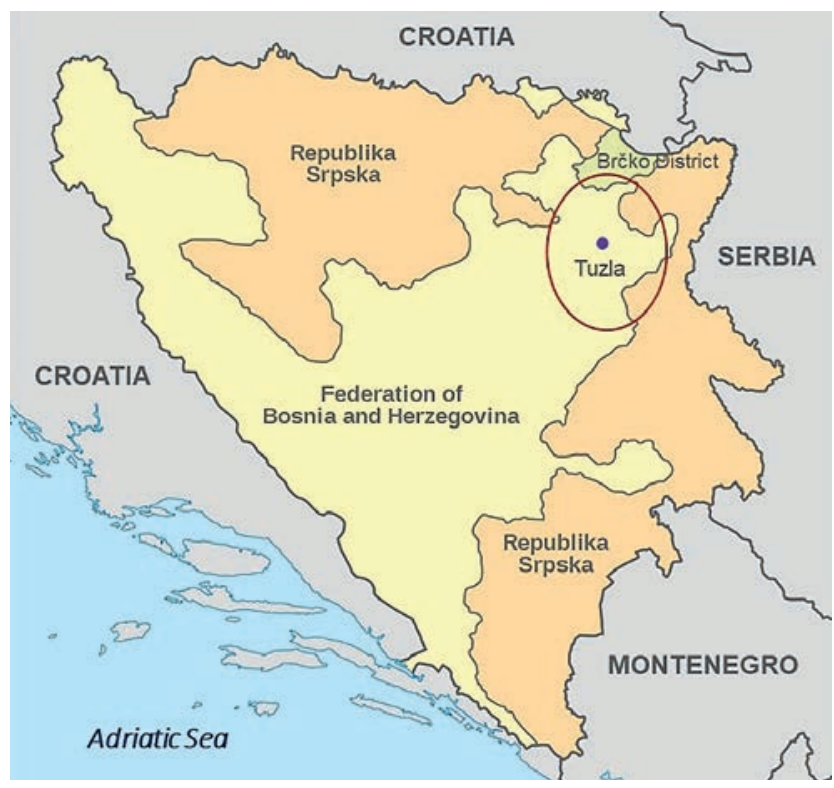

Fig. 1 Bosna and Herzegovina: administrative structure and study area. war and post-war life, took place in the post-war Bosna and Herzegovina consisting of two entities based on its constitutional and administrative structure: the Federation of Bosnia and Herzegovina (FBiH) and Republika Srpska (RS) and Brčko District - Fig. 1.

Bosnia and Herzegovina (total area 51,129 $\mathrm{km}^{2}$ ) is home to members of numerous ethnic groups and around $60 \%$ of the population is rural. According to the Ministry for Human Rights and Refugees of Bosnia and Herzegovina (2006), from the beginning of the three-year war until signing the Dayton Agreement, about 2.2 million persons, which makes almost a half of the pre-war domicile population, were forced to leave their homes and move. Out of that number, more than a million people were displaced within Bosnia and Herzegovina and around 1.2 million people have sought the refugee protection abroad. In the early post-war years, estimates of the number of the victims in the civil war oscillated between a wide range of 25,000-329,000 (Tabeau, Bijak 2003), but most often in the range between 200,000-250,000. About 15,000 persons were recorded as missing (Ministry for Human Rights and Refugees 2006). According to later estimates, the number of victims oscillates approximately around 100,000 (Tabeau, Bijak 2005). A comparison of the 1991 and 2013 censuses shows that the absolute population of all ethnic groups decreased by almost 0.8 million (from 4.377 million to 3.531), with the share of Bosniaks increasing by $6.6 \%$ and the share of Serbs, Croats and others declining. (Institute for statistics of FB\&H 2016).

The research of the life paths of the examined group of Bosniaks concerns the territory of the former Yugoslavia, the area in which all respondents lived, migrated or were forced to move before the period of armed conflict, during the war events or after the end of conflict.

The study area in which structured interviews were carried out is in the northeast Bosnia (Fig. 1), a part of territory called Podrinje in village Mihatovići near city of Tuzla. In Mihatovići there is one of the refugee centres, mainly for Bosnian Muslims, and probably the largest one in the canton of Tuzla. During the war, the city of Tuzla has never been seriously attacked and was a rare oasis of "normality" in the Bosnian war. When the Bosnian war ended, the return process was agreed, although there remains a significant number of displaced persons, refugees and other conflict-affected persons of concern who are in need of durable solutions. In this mountainous area, about 10 kilometres outside the city of Tuzla, transport options to the camp are limited. A narrow road leads to the collective settlement that was built mostly from sources of the Norwegian People's Aid at the beginning of the war (Lisica 2013). The refugee camp Mihatovići is situated on a hill and was designed for the temporary housing units. Officially in 2016, there were still 161 residents living in this camp (Catholic Relief Services 2016) and according to the City Administration, 


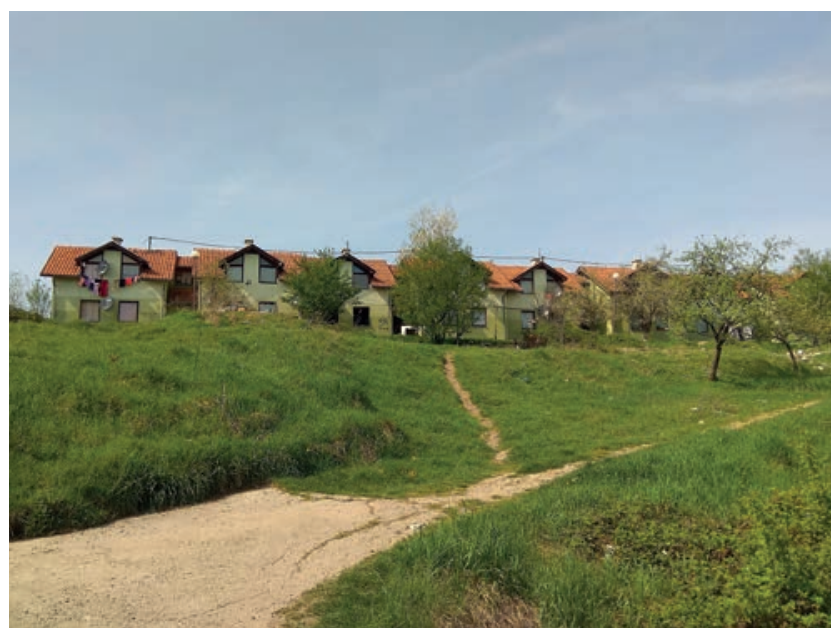

Fig. 2 Refugee houses in Mihatovići.

in 2018 there were 286 residents (http://www.tuzla .ba). Many of the residents who still live in the rundown refugee camp are relatives and survivors of the 1995 genocide in Srebrenica. These people mostly came from Srebrenica but also from the nearby settlements such as Bratunac, Zvornik or Vlasenica.

Besides the refugee houses (Fig. 2), the refugee camp Mihatovići has two little grocery shops and one primary school (Fig. 3). The Service for Veterans' and Disability Protection, Residential Affairs and Return of the City of Tuzla is in charge of the collective centre. According to data available in 2015, the government representation planned to close the "collective settlement" of Mihatovići in 2017. But since then, the refugee camp Mihatovići provided services for some marginalised social-economic group which struggles with poverty.

\subsection{Data and methods}

In this paper we study the activity patterns of a selected group of 32 displaced individuals who were directly affected by war while preserving the individualities of the group members.

Only 6 men but many more women (26) were represented in this group. This disparity resulted from a real situation among displaced persons, as a significant number of men died either during the defensive war or were later killed. We followed their life-paths starting from the pre-war period (1990) to the year 2018. From the total number of 32 respondents we selected 5 persons ( 3 females and two males) with different life destinies and on the example of their life-paths we analysed in more detail the complexity of their behavioural patterns (3D graphs in Figs. 2-6). The data allowed us to gain a new insight to the behaviour of these individuals before, during and after the war. It contributes to understanding of activities of people affected by war conflicts in physical space and chronological time in specific political,

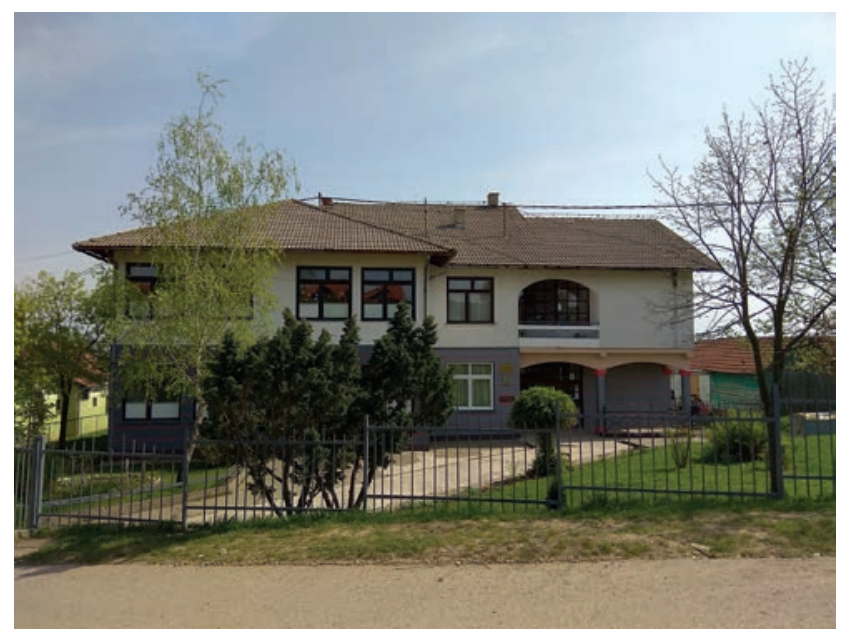

Fig. 3 Primary school in Mihatovići.

economic, socio-cultural, institutional, and geographical contexts. Also, we can compare similarities and differences in the life of our respondents.

In order to collect survey data, the time-geographical approach based on records of activities in timespace was applied. The time-space activity diary is a significant instrument for a sensible analysis of lifepaths of individuals. The use of time-space diaries expanded after the introduction of Hägerstrand's time geography into human geography (Hägerstrand 1970). The development of geographic information systems (GIS) and computational capabilities in the last few decades expanded possibilities in time-geographic research (Kwan 2004) and facilitated the analysis of time-space diaries (Couclelis 1999). Activity diaries collect information on the activity content: the time that an activity episode starts and ends (when), the geographical context, i.e. the spatial location where the activity takes place (where), the social context, i.e. the person(s) involved in the event (with whom), and the use of transportation mode(s) enabling access the place where the activity occurs (how). There are several additional dimensions for which information is collected, e.g. the respondent's feelings and emotions during activities (Schwanen 2009). This method recording individuals' activities and movement in time and space may facilitate reflections on changes in the patterns of activities and may enable a deeper understanding of relationships in community (Díaz-Muňoz 1999; Ellegård 1999). It illustrates practices and activities in geographical and social context. The diary method provides an effective approach to collect data that enables the systematic study of activities of individuals and was applied in several scientific disciplines (e.g. Couclelis 1999; Schwanen 2009 and Miller 2017).

Data collection for this research was organized in April 2018. Respondents were interviewed and asked to generate an "ex-post facto" open time-space activity diary. One of the key challenges within the mixed 
methods research is the successful integration of quantitative and qualitative data during analysis and interpretation. The integration of the qualitative and quantitative data can bring a different perspective to the research and can contribute to the understanding of complex research problems (Tariq and Woodman 2013). We have used 3D maps to visualize the trajectories of individuals during the period of less than three decades. We also conducted in-depth interviews with the same individuals in which they expressed their responses to the questions. Oral history interviews may concern a very specific subject or cover an entire lifespan or trace a complex issue that unfolds over time offering the geographers the opportunity to examine the complexities and intricacies of place (George, Stratford 2010). This method is especially applicable to the study of memory and place, but can be useful to geographers in many sub-fields of the discipline (Ward 2012).

Nationality, internal displacement and housing in the territory of former Yugoslavia in the pre-war period were included in the selection criteria for the group of respondents. The main challenge associated with the data collecting was to reach a desired group of people. This was possible using the snowball sampling, which works as a chain referral (e.g. Goodman 1961; Cohen, Arieli 2011; Rochovská et al. 2014). It helped to develop a research sample. In this method, the sample group grows like a rolling snowball. It has been very useful in investigating a wide variety of specific population (for example marginalised), and thus it is possible to agree with Cohen, Arieli (2011) who are claiming that the snowball sampling is useful in collecting data in conflicting environments. We realize that this relatively small set of respondents does not make it possible to generalize the interpretation of behavioural patterns of internally replaced persons in Bosnia and Herzegovina. However, it allows us to better understand the extreme complexity and emotional impact of the war and post-war situation on the example of individuals who have so far failed to cope with the return to the post-war conditions of everyday life.

\section{Results}

The analyses of in-depth interviews and time-space diaries helped us better understand importance of life-paths and their bonding with life activities of people affected by war conflicts in a physical space and chronological time in concrete economic, geographical, socio-cultural, institutional, and political contexts.

In-depth interviews were useful when we wanted to know detailed information about a person's thoughts and behaviours or to explore new issues in depth (related to war and post-war events). Interviews were used to provide context to other data (time-space activity diaries), offering a more complete picture of what happened in the life of the respondents and why.

Records in time-space diaries of our respondents contained six groups of data. The first group refers to time, the date. The individual described the path starting at the point of birth till 2018. The second group refers to activity (e.g. study, employment, military service or escaping the war conflict locality). The third set of data (geographical context - place) identifies the geographical location where the activity took place (e.g. Srebrenica, Potočari, Kladanj, Tuzla, etc.). The fourth describes social context - with whom they did that activity specified in terms of their relations with the respondent (e.g. family members, friends, and partners). The fifth data set referred to the transport mode (walking, using tractors, lorries or cars, etc.). And the sixth data set contained some notes such as getting married or involvement in violence, explanation of feelings in specifics situations. This helped us discover their influence upon and relations with any other event. The basic time unit was one month, but in case of forced and urgent migration we used even a day as a basic unit. The time-space diary technique/ method has been complemented by audio recording. The interviews were structured to be compatible with the time-space diaries. However, the respondents had the opportunity to answer freely in their own words without significant interference from the person who conducted the interview.

The diaries that we have analysed were based on personal histories of 32 respondents ( 6 males and 26 females), which we collected during April 2018 and then recorded their trajectories. In one-to-one personal interviews, respondents were questioned retrospectively about their personal history, starting at the point of birth through the time of armed conflicts till present. All of them are Bosniaks by nationality, Muslims by religion and with Bosnian-Herzegovina citizenship. The average age of interviewees is 51.2 years. Among all respondents 12 of them completed the elementary/basic school of 8th grades, but most of them have not completed it and reached only a few levels of the primary or secondary education. Only 5 persons completed secondary school. There was also one respondent who had no education. Thirty respondents are in age group considered economically productive and only two respondents are in the post-productive age (working age population 15-64). Of all respondents only two persons are self-employed in their own shops in the camp. The rest of them depend upon state compensation for displaced persons or some of them occasionally work. They came from Republic of Srpska, but after the ethnic cleansing in 1995 they were forced to move to the Federation of Bosnia and Herzegovina.

Before the war their households were mostly in rural areas around Zvornik, Bratunac, Srebrenica or Vlasenica in highlands where the economically active population was employed in agricultural sector. 
According to the widespread norms, with regard to woman's role and her behaviour, girls were required to skip attending school classes and to stay at home and help with household duties and farming until they reached a "marriageable age". When they leave the family and get married little is expected to change in the new family. Men have been encouraged to go out and seek jobs in order to support financially their families. The consequences of these traditional models manifested later in the post-war transition when they found themselves in an urban environment with lacking education and no work experience, and unable to adapt to the changing market conditions.

Important aspects of the time-space behaviour of all thirty two interviewed are presented in Tab. 1. Almost three decades of our analysis were divided into three periods: pre-war period in Bosnia and Herzegovina (1 January 1990 - 6 April 1992), war times (7 April 1992 - 14 December 1995) and post-war period (15 December 1995 - 16 April 2018) ending in the time when survey was conducted. It is evident from Table 1 that war and post-war period is characterized by complicated life-paths in some cases with numerous movements and shorter or longer stays in places (stations). During analysed war-period, ten of the twenty-six interviewed women experienced/ underwent five or more relocations in order to save their own lives and the lives of family members, especially children. In the post-war period, the number of relocations decreased. Only in five records of activity diaries we can find five or more movements. A specific case is a man (42 years old) who worked as a construction worker in 10 localities (apart from Bosnia and Herzegovina, also in Slovenia, Italy, Austria, and Germany). During movements apart from overcoming relatively long distances on foot, they used various (sometimes unusual such as tractors and lorries/trucks) transportation means to reach stations where they could survive for some time. Stations in terms of the time-geographical terminology are spatial locations (places) where activities between relocation periods took place. The most of respondents were forced to migrate by war and post-war events. Records in time-space diaries also enabled us to analyse motivations to move or stay. Pre-war motivations to move were induced by family reasons and job opportunities especially for male population. Motivation factors changed during the war. Apart from the fact that several respondents were motivated to join their families, several war-endangered persons were forced to leave their homes and directed by domestic and international institutions to new localities.

A qualitative data collection method, in-depth interviews, offered the opportunity to capture rich, descriptive data about interviewees' behaviour, attitudes, perceptions and experience from the pre-war to post-war period, and the complex processes in between. All our respondents in the Mihatovići camp have been exposed to multiple pre-and post-migratory
Tab. 1 Spatial behaviour of respondents from Eastern Bosnia (1990-2018): movements and stations.

\begin{tabular}{|c|c|c|c|}
\hline \multirow[b]{2}{*}{$\begin{array}{l}\text { Respondents } \\
\text { (Age-Gender) }\end{array}$} & \multicolumn{3}{|c|}{ Number of movements / Number of stations (places) } \\
\hline & $\begin{array}{c}1 \text { January } \\
1990-6 \text { April } \\
1992\end{array}$ & $\begin{array}{c}7 \text { April } 1992- \\
14 \text { December } \\
1995\end{array}$ & $\begin{array}{c}15 \text { December } \\
1995-16 \text { April } \\
2018\end{array}$ \\
\hline 84-F & $0 / 1$ & $7 / 8$ & $0 / 1$ \\
\hline $68-\mathrm{F}$ & $0 / 1$ & $3 / 4$ & $1 / 2$ \\
\hline $63-\mathrm{F}$ & $0 / 1$ & $3 / 4$ & $6 / 5$ \\
\hline $60-\mathrm{F}$ & $0 / 1$ & $2 / 3$ & $1 / 2$ \\
\hline $59-\mathrm{F}$ & $0 / 1$ & $6 / 5$ & $2 / 2$ \\
\hline $58-\mathrm{F}$ & $0 / 1$ & $6 / 8$ & $1 / 2$ \\
\hline $58-\mathrm{F}$ & $0 / 1$ & $2 / 3$ & $0 / 1$ \\
\hline $57-\mathrm{F}$ & $0 / 1$ & $5 / 6$ & $1 / 2$ \\
\hline $56-\mathrm{F}$ & $0 / 1$ & $7 / 8$ & $1 / 2$ \\
\hline $55-\mathrm{F}$ & $1 / 2$ & $3 / 4$ & $0 / 1$ \\
\hline $55-\mathrm{F}$ & $0 / 1$ & $4 / 5$ & $2 / 3$ \\
\hline $51-\mathrm{F}$ & $1 / 2$ & $3 / 4$ & $0 / 1$ \\
\hline $52-\mathrm{F}$ & $0 / 1$ & $4 / 5$ & $0 / 1$ \\
\hline $47-\mathrm{F}$ & $0 / 1$ & $6 / 7$ & $1 / 2$ \\
\hline $46-\mathrm{F}$ & $1 / 2$ & $5 / 6$ & $1 / 2$ \\
\hline $46-F$ & $0 / 1$ & $10 / 9$ & $4 / 3$ \\
\hline $45-\mathrm{F}$ & $0 / 1$ & $2 / 3$ & $0 / 1$ \\
\hline $44-F$ & $0 / 1$ & $4 / 5$ & $1 / 2$ \\
\hline $44-F$ & $0 / 1$ & $5 / 6$ & $9 / 6$ \\
\hline $43-\mathrm{F}$ & $0 / 1$ & $3 / 4$ & $7 / 8$ \\
\hline $40-\mathrm{F}$ & $0 / 1$ & $1 / 2$ & $6 / 5$ \\
\hline $40-\mathrm{F}$ & $0 / 1$ & $2 / 3$ & $3 / 4$ \\
\hline $39-\mathrm{F}$ & $0 / 1$ & $6 / 7$ & $1 / 2$ \\
\hline $38-\mathrm{F}$ & $0 / 1$ & $4 / 5$ & $1 / 2$ \\
\hline $31-F$ & $0 / 1$ & $1 / 2$ & $1 / 2$ \\
\hline $30-\mathrm{F}$ & $0 / 1$ & $3 / 4$ & $3 / 4$ \\
\hline 64-M & $0 / 1$ & $1 / 2$ & $7 / 5$ \\
\hline $62-M$ & $0 / 1$ & $5 / 4$ & $3 / 3$ \\
\hline 59-M & $0 / 1$ & $3 / 4$ & $1 / 2$ \\
\hline 59-M & $0 / 1$ & $7 / 5$ & $1 / 2$ \\
\hline $42-M$ & $0 / 1$ & $1 / 2$ & $11 / 10$ \\
\hline 40-M & $0 / 1$ & $2 / 3$ & $3 / 3$ \\
\hline
\end{tabular}

traumatic experiences, it was therefore essential for us to be aware and respectful for their vulnerability. The total number of questions in this in-depth interview was 27 and most of questions were related to the key aspects of their lives.

Prior to the conflict, only one respondent had the opportunity to witness a case where members of a particular nationality or religion were preferred. The other 31 respondents answered negatively. Only less than a tenth of respondents experienced personally some inconvenience before conflicts in the 1990s due to nationality or religion. One of these answers was: yes, from neighbours in 1992 saying, we Muslims 
have caused the war and wanted the war. This did not imply our decision to move. Until they started killing, no one left their home.

All respondents agreed that if there were no armed conflicts, they would still remain in the original region/ place of residence. Nearly two-thirds of respondents think that the propaganda of some nations affected the development of the conflict in the former Yugoslavia. On the contrary, one-fifth of the respondents answered no. Most of the questioned Bosniaks (two thirds) believe that the faith, religion in the milieu in which they formerly lived, played a very important role. Opinions on whether official attitudes of church leaders played an important role in promoting their own interests and contributing to the spread of conflicts were different. In thirteen cases the answers were positive, twelve respondents answered no and seven did no comment or were not sure. It is evident from the positive answers that the church leaders did not make sufficient efforts to calm the situation and promote reconciliation. A large number of respondents (24) believe that political leaders abused religion in their favour. The war conflict also had an impact on marriage. Five respondents also reported ethnically mixed marriages in their neighbourhood that have ended in a divorce after the war conflic began.

The vast majority of respondents said they did not intend to return to localities where they used to live before the war. The main reasons were as follows: their homes and properties were either burned or taken away. Over time some of them managed to sell what they owned before the war. The important reason why they plan to stay at the place of their present stay is a feeling of security. And it has often been accounted that those places have no more importance for them than they had before the war. These reasons suggest that the move was provisionally terminated with the prospect of settling permanently.

The interviewees also expressed their views on the conditions under which they would return to live in the environment they came from. Less than a third would return if they had a house, less than a third, assuming there were schools, job opportunities, shops, doctors, better conditions. The retreats gave the following reasons: "if my husband was not killed", "if my relatives were alive". Less than a third is determined to never return.

Moving away is associated not only with the changes in housing and employment, but also with coming into a different cultural, social and economic environment that had a significant impact on the lives of the respondents. Nearly two-thirds reported a very negative impact, especially a deteriorated state of health (i.e. mental illness, diabetes, heart disease, and so on). For many, the beginning after war was very difficult (frequent moves) and in some cases the family is still not together.

Nearly two-thirds of respondents feel safe when they visit their former country/region, respectively, they moved out from. More than a third does not feel safe. According to the Bosnian respondents, the relations among neighbours in the domestic community before the war were good (21) and very good to excellent (11). Most of the participants in the interviews (31) would support changes in the place they came from, mainly political and economic changes (one third), some (7) would promote social, cultural and community changes (changes in local environment).

As an example of visual interpretation of timespace diaries in 3D graphs we have selected five respondents from Kostijerevo (Fig. 2), Pribidoli near Srebrenica (Fig. 3), Radovčići near Srebrenica (Fig. 4), Liplje (Fig. 5), and Vlasenica (Fig. 6). A selected group

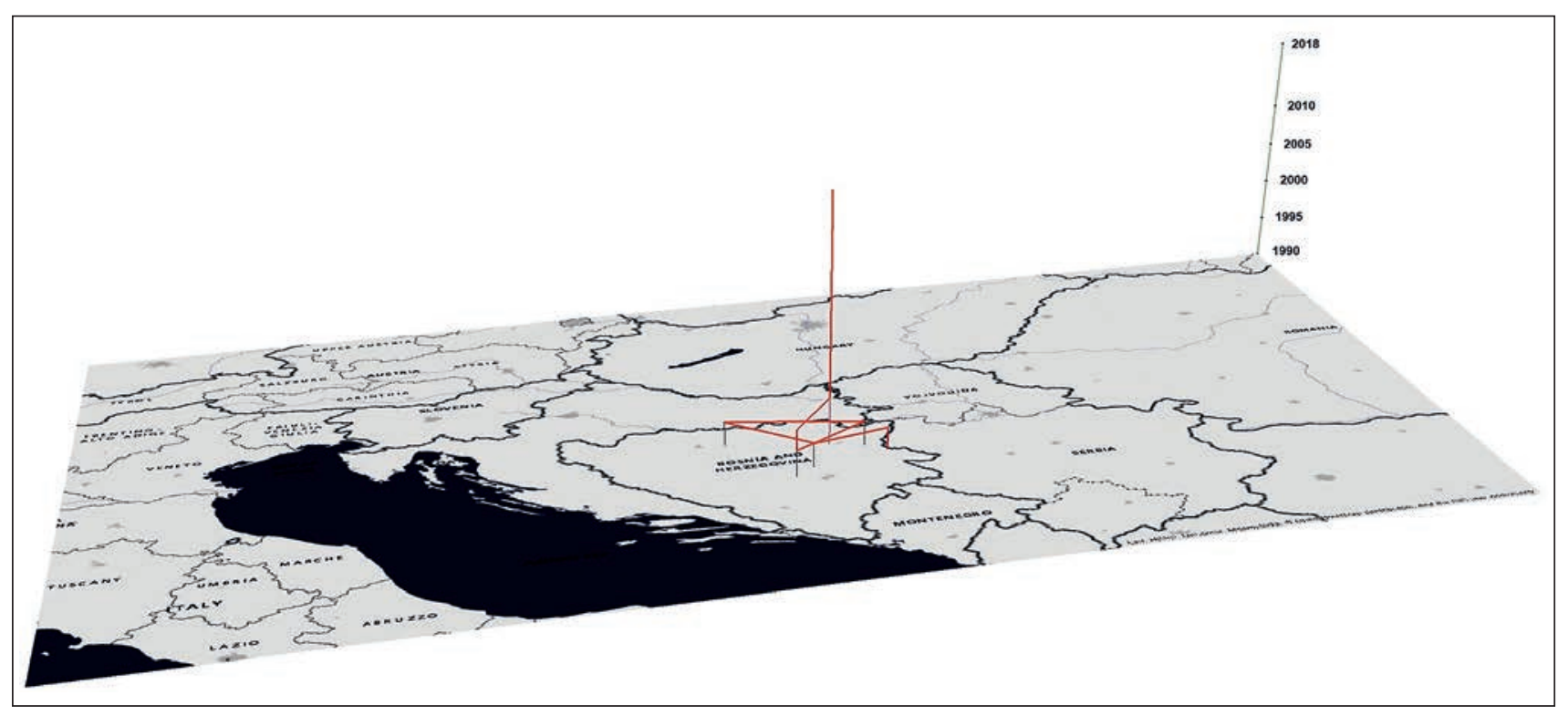

Fig. 4 Life-path of 84 years old female living in Mihatovići camp. 
of 5 respondents, represented by 3 women and 2 men, shows different types of life paths influenced by different life situations and different factors Vertical line in the graph represents the time context, duration of some activity in certain geographical space of one individual. Every interruption or diversion meant change of direction of the movement of time axis and its duration. Time span used in the construction of 3D graph is from 1990 until 2018. Before the war there were no important changes in place of living recorded i.e. if not for the war, the female respondents would have lived all their lives in the places they were driven out of. But because of the war they had to hide and often change their accommodation until they settled in Mihatovići camp.
The oldest respondent, 84 years old female from the village of Kamenica, a woman who did not attend school, represents the type of Muslim female population of Bosnia of the older generation (Fig. 4). She is a widow, mother of 9 children, three of whom died during the civil war in the Srebrenica area. Until July 1992, she lived with her family in Kostijerevo. In July and August 1992, she and her family were forced to leave their homes. On foot, through the mountainous forests, they fled north to the village of Kiseljak. They spent more than 2 years there in the detention centre. In June 1995, she has been internally displaced to the refugee centre (community/collective centre) Mihatovići. From that time until the date of the interview, she spent almost 23 years in that facility.

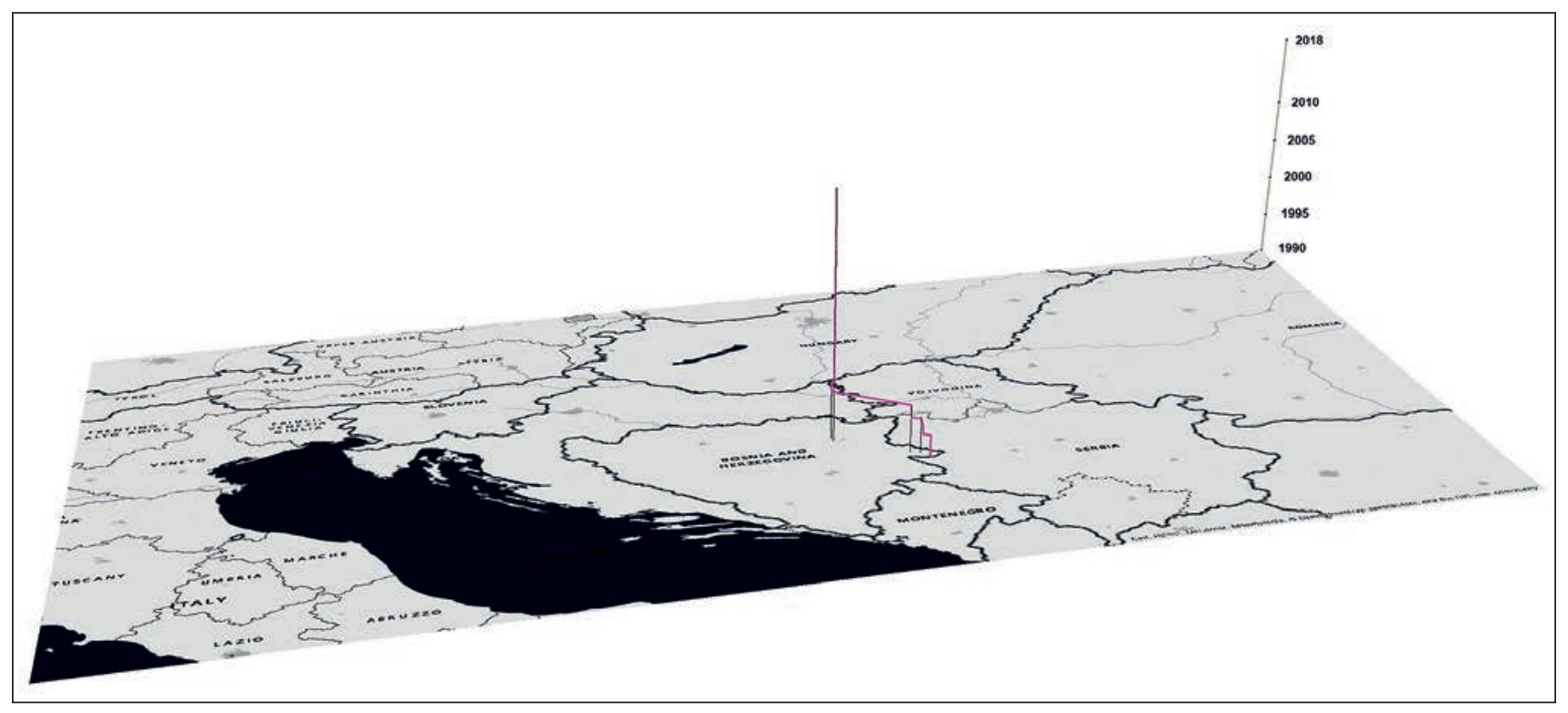

Fig. 5 Life-path of 56 years old female living in Mihatovići camp.

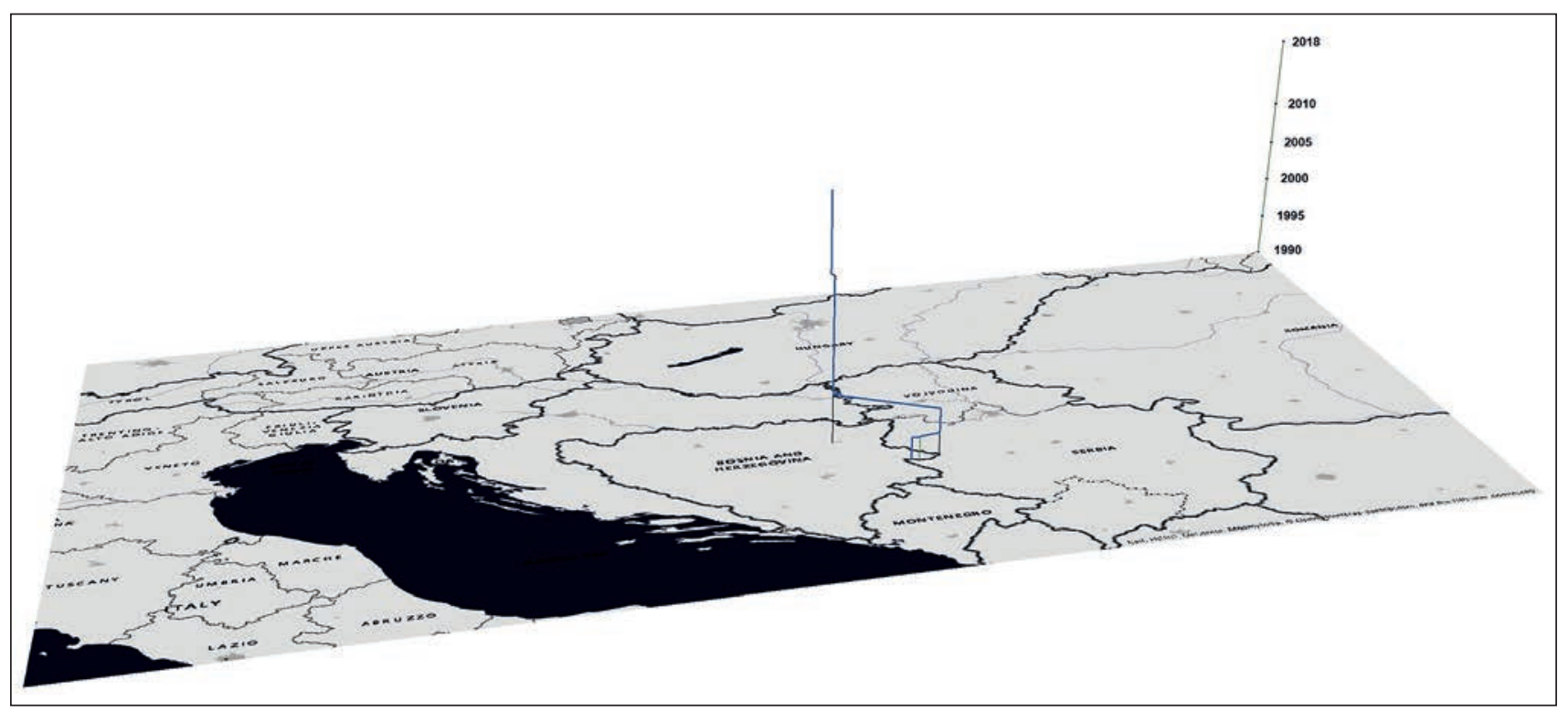

Fig. 6 Life-path of 58 years old female living in Mihatovići camp. 
Another Muslim woman aged 56, born in the village of Pirići, with incomplete primary education (4 years of primary school), a mother of three children (Fig. 5). In April 1992, at the beginning of the conflict in Bosnia, she left the village of Pribidoli and after short stays in several localities she got to Srebrenica with her family (husband, children and mother-in-law). During the war she became a widow - her husband died there). After almost two years spent in Srebrenica they were forced to move on foot and bus to Potočari (north of Srebrenica). After more than a year spent in detention centres, gets together with children to the refugee centre (community/collective centre) Mihatovići.

The life-path of a 58 years old Muslim woman with completed primary education, a widow with 2 children begins in the small settlement of Delić near Srebrenica (Fig. 6). After being married, she starts a family in the village of Radovíci. She left their home in June 1992 and hid with her family and neighbours in the mountains for two months. From August 1992 to July 1995 they live in the village Petriča (on the border with Serbia) together with their relatives. In July she lost her husband (shot in Potočari near Srebrenica). After three months in the Ši Selo near Tuzla, she leaves with children and some relatives in Bukinje near Tuzla, where they lived until May 2009. From there, she moves with one son to the refugee centre (community/collective centre) Mihatovići.

Differences between movements in the case of two men (62 and 59 years old) were that before the war the older (62) Bosnian Muslim (Fig. 7), father of two

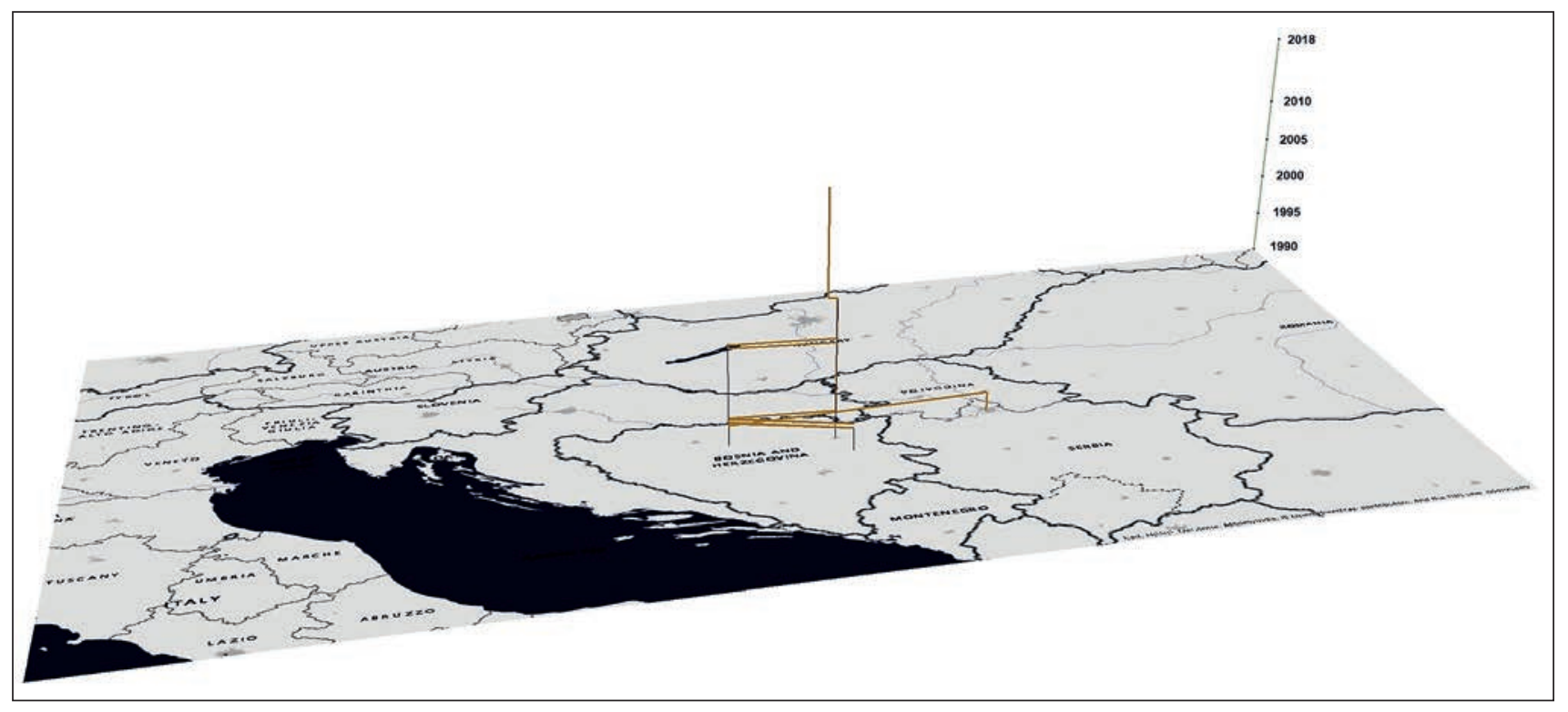

Fig. 7 Life-path of 62 years old male living in Mihatovići camp.

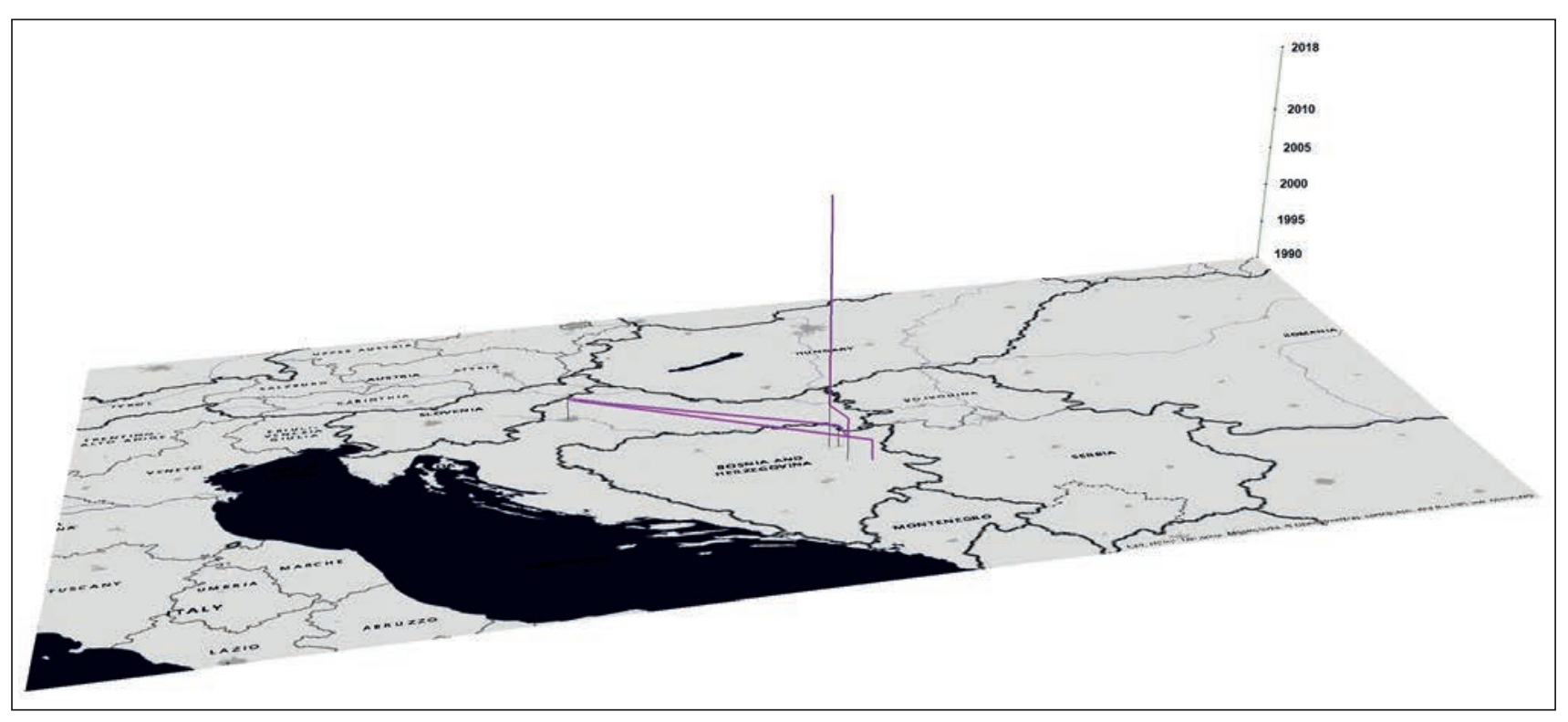

Fig. 8 Life-path of 59 years old male living in Mihatovići camp. 
children was long-term employed in Belgrade and younger (59), also Bosnian Muslim (Fig. 8), father of two children in his home town of Vlasenica. At the beginning of the war in 1992 both of them were in their home towns and became soldiers of the territorial defence. During this period, 59 years old Bosniak was sent to the military training in Zagreb and after that he joined the army in Tuzla and took part in the fighting around Tuzla. In 1995, he was demobilized and since then he changed two localities of his accommodations before he entered Mihatovići camp in the last part of 1995. Older respondent of Bosnia origin (62) was demobilised also in 1995 and since then he spent more than 6 years in Tuzla. After that, for couple of months he returns to Liplje, but because of lack of financial sources he left his birthplace Liplje for Tuzla. Since April 2006 he was replaced together with his wife and children to Mihatovići camp.

\section{Discussion}

In our empirical research we applied the time-geographical approach which seems to be a convenient foundation for mapping and modelling migration processes and patterns of individuals in the conflict and post-conflict time. The methodological concept is based on works of Torsten Hägerstrand which state that in time-space the individual describes a path starting at the point of birth and ending at the point of death (Hägerstrand 1978). Every form of human meeting is preceded and succeeded by movement in space. Four dimensional view of the world is a view which conceptually respects the continuity and interdependence of matter, space and time (Pred 2005). The essential module of time geography is placed on individuals' mobility, that is, the life-path in which people connect with each other in couples or groups at various points and for various purposes. The lifepath can be understood in a variety of temporal and spatial scales, from a day-path to a lifetime. The timespace diaries helped us to create a more complex picture of how individuals interacted with each other in a life affected by war conflicts and post-war difficult situations. Detailed records made it possible to identify some social and economic contexts in which our respondents lived before the war comparing to their present situation (Schwanen 2009).

The use of a data set from a longer period (a biographical time scale) leads to some differences with respect to how the time-space paths should be interpreted compared to short period (e.g. daily trajectories). Our results are consistent with Frändberg's statement: "When the time scale is years and decades rather than hours and days, the representation of movement is by necessity very selective" (Frändberg 2008: 19).

The GIS as information technology is placed at the intersection of several different views of space and time (Couclelis 1999). New perspectives on space and time in a war and post-war life of affected population were added to the traditional ones, the cognitive and the socio-cultural. It seems to be very efficient and the question of space and time in the analyses of the complicated life-paths (formed by external circumstances) is becoming more complex.

Wars have long term effects not only on the populations in the conflict zones, but also on populations beyond these territories (e.g. through the flight of refugees and by the economic impacts). The landscapes of war zones are well marked, on the one hand by damaged buildings and infrastructure, destroyed landscape icons (such as churches and mosques), ravaged cities, abandoned lands, on the other hand by various new elements which appeared in the landscape during post war rebuilding. Much of the post-conflict geographical research is focused on the political, social and economic consequences of wars (O'Loughlin 2009). Growing attention is now being given to the number of behavioural geographical aspects (e.g. distribution of refugees and forced migrants near conflict zones, long distance migration and refugee flows, large and diverse populations in poor regions involved in a struggle over power, representation, and resources such as food, employment, education, and healthcare).

There are an increasing number of time-geographically-inspired studies on lives of people in vulnerable situations, studies carried out in various academic disciplines, such as human geography, sociology, political science, social change studies, psychology, psychiatry, social work and occupational therapy (Ellegård 2019). Many of these applications, as well as the application in our study, using the time-geographic concepts and visualizations can help to understand the life situation of these people. There is a potential to combine time-geographic diaries with "the postwar treatment programmes" and discussions on motivation to realize changes in order to get better quality of their lives.

\section{Conclusion}

The results of the analysis of the group of respondents in our study have, on the one hand, a limited informative value, on the other hand they describe in more detail the difficult situation of a selected sample of the population of war and post-war Bosnia and Herzegovina. As far as the time-space behaviour patterns of studied group of Bosniaks are concerned, in pre-war period it was a traditionally conservative population characterized by significantly different time-space behaviour of male and female population. Women were mostly not used to moving or migrating far from the place of their birth (or stay), except for marriages. In many cases, men migrated more often, with job opportunities being the main motive. 
Unfortunately, the war became the main push and pull migratory factor, which forced to them to escape the war zone and became long term internally displaced persons. We have paid special attention to the geographical, social and other contexts recorded in their time-space diaries because they are very important for a deeper understanding of behaviour of individuals affected by war not only in time of conflict but also in post-conflict period. Thirty two men and women with complicated and disturbed life trajectories survived sudden and unwanted changes of locations. In particular, they had in common the history of former Yugoslavia although their experiences of the war conflict and post-war events have been different and subjectively experienced and perceived in different ways. With the ever changing relations in the war and post-war environment they got into trouble. Similarly as Lundén (2003) we can state that the real individual reasons for their life-choices at different situations will never be completely clear. Community and family relations, personal economic situation, religion and ethnicity may have in certain cases more impetus than political situations in war and post-war periods.

The collection of time-space diaries was tailored to specific research questions focused on people struggling with difficult life circumstances. It was part of strategy for our research with a particular interest in the multiplicity and particularity of people's experiences of life in the conflict and post-conflict environment. It was based on a systematic ex-post record of the person's use of time over the period lasting almost three decades including the spatial coordinates of their activities locations. The method of diary supplied information for the analysis of life paths of studied Bosniaks, who to these days have not found a way to deal with the consequences of the war and integrate into the newly formed post-war Bosnian society. This kind of research is considered to be absent, so the research presented in this paper could be perceived as one of the first studies with an original empirical material which could serve for the development of more complex interdisciplinary research projects combining theories of war and post-war marginalization and integrating experiences of people in war-induced marginalized groups with time-geography.

We can state, similarly as Ellegård (2019), who mentions in her publication on concepts, methods and applications in time geography, that the individual life-path concept also helps reveal what consequences arise for other individuals in life-threatening situations from one individual's decisions to act in a certain way. In-depth structured interviews and the visualizations of life-paths offered the possibility to generate questions which could be posed thanks to detailed information about the life constraints and experience of people affected by the war. Time-geographic analyses can be useful to show to authorities (even international) that the rules and programmes they have set up in post-conflict territories are not always functional.

\section{Acknowledgements}

This work was supported by the Scientific Grant Agency VEGA (grants number 1/0049/18 and 2/0013/18). The authors would like to thank Dr D. Szatmári from the Institute of Geography, SAS for his helpful advices on visualization issues (Figs. 2-6) in this paper.

\section{References}

Beširević, N. (2010): Ethnic Conflicts in the Former Yugoslavia as a consequence of nation-state building. Treatises and Documents. Journal of Ethnic Studies 61, 42-61.

Blagojević, B. (2004): Ethnic Conflict and Post-conflict Development, Peacebuilding in Ethnically Divided Societies. (A dissertation). Rutgers, The State University of New Jersey, USA. http://dga.rutgers.edu/sites /default/files/uploads/2012/10/bojana.pdf (10 October 2017).

Blagojević, B. (2009): Causes of Ethnic Conflict: A Conceptual Framework. Journal of Global Change and Governance 3(1), 1-25

Castles, S. (2003): Towards a Sociology of Forced Migration and Social Transformation. Sociology 37(1), 13-32, https://doi.org/10.1177/0038038503037001384.

Castree, N., Rogers, A., Kitchin, R. (2013): A Dictionary of Human Geography. Oxford: Oxford University Press, https://doi.org/10.1093/acref/9780199599868 .001 .0001 .

Catholic Relief Services (2016): Strategija neprofitnosocijalnog stanovanja grada Tuzle za period 2017-2021. Tuzla: Catolic Relief Services. Printed promotional material.

Cohen, N., Arieli, T. (2011): Field research in conflict environments: Methodological challenges and snowball sampling. Journal of Peace Research 48(4), 423-435, https://doi.org/10.1177/0022343311405698.

Collier, P. (2000): Economic Causes of Civil Conflict and Their Implications for Policy. Development Research Group World Bank, https://reliefweb.int/sites /reliefweb.int/files/resources/B7598814338CA6 DEC1256C1E0042BE82-civilconflict.pdf (10 October 2018).

Collier, P., Hoeffler, A. (2004): Greed and Grievence in Civil War. Oxford Economic Papers 56(4), 563-595, https:// doi.org/10.1093/oep/gpf064.

Connor, W. (1994): Ethno-Nationalism: The Quest for Understanding. Princeton: University Press.

Couclelis, C. (1999): Space, time, geography. In: Longley, P. A. et al. (eds.), Geographical information systems, principles and technical issues, 29-38. New York: John Wiley and Sons.

Díaz-Muňoz, M. A., Salado-García, M. J., Díaz-Castillo, C. (1999): A teaching approach to time-geography: Some results of an educational experiment. GeoJournal 48(3), 159-166, https://doi.org/10.1023/A:1007019406593. 
Drbohlav, D., Uherek, Z. (2007): Reflexe migračních teorií. Geografie - Sborník České geografické společnosti 112(2), 125-141, https://doi.org/10.37040 /geografie2007112020125.

Drbohlav, D. (2011): Determinants of Migration. In: Grabowska-Lusinska, I., Drbohlav, D., Hars, A., (eds.), Immigration Puzzles; Comparative Analysis of the Czech Republic, Hungary and Poland before and after Joining the EU. Saarbrücken: LAP Lambert Academic Publishing.

Ellegård, K. (1999): A time-geographical approach to the study of everyday life of individuals - a challenge of complexity. GeoJournal 48, 167-175, https://doi.org /10.1023/A:1007071407502.

Ellegård, K. (2018): Thinking Time Geography: Concept, Methods and Applications. London: Routledge, https://doi.org/10.4324/9780203701386.

Frändberg, L. (2008): Paths in transnational time-space: representing mobility biographies of young Swedes. Geografiska Annaler Series B Human Geography 90(1), 17-28, https://doi.org/10.1111/j.1468-0467.2008 .00273.x.

George, K., Stratford, E. (2010): Oral history and human geography. In: Hay, I. (ed.), Qualitative Research Methods in Human Geography, 139-151, Toronto: Oxford University Press.

Gold, J. R. (2009): Behavioral Geography. In: Kitchin, R., Thrift, N. (eds.), International Encyclopedia of Human Geography I, 282-293. Amsterdam-Oxford: Elsevier, https://doi.org/10.1016/B978-008044910-4.00665-9.

Golledge, R. G. (2008): Behavioral Geography and the Theoretical/Quantitative Revolution. Geographical Analysis 40(3), 239-257, https://doi.org/10.1111 /j.1538-4632.2008.00724.x.

Golledge, R. G., Stimson, R. J. (1990): Analytical behavioural geography. London: Routledge.

Goodman, L. A. (1961): Snowball sampling. Annals of Mathematical Statistics 32(1), 148-170, https://doi.org /10.1214/aoms/1177705148.

Hägerstrand, T. (1970): What about people in regional science? Papers in Regional Science 24(1), 7-24, https:// doi.org/10.1111/j.1435-5597.1970.tb01464.x.

Hägerstrand, T. (1978): Survival and arena: on the lifehistory of individuals in relation to their geographical environment. In Carlstein, T., Parkes, D. and Thrift, N. J. eds., Timing Space and Spacing Time, Vol. 2: Human Activity and Time Geography. 122-143, New York: Wiley.

Horowitz, D. (1985): Ethnic groups in conflict. Berkeley: University of California Press.

Institute for statistics of FB\&H (2016), http://fzs.ba/ wp-content/uploads/2016/12/Konacni-rezultatiPopisa-2013.pdf (accsssed 15 January 2019).

Hutchinson, J., Smith, A. D. (1996): Ethnicity. Oxford: Oxford University Press.

Ira, V. (1997): The perception of potential ethnic tensions (the region of East Slovakia and Northeast Hungary). Földrajzi Értesítő: Geographical Bulletin 46(3-4), 161-171.

Ira, V. (2001): Geografia času: prístup, základné koncepty a aplikácie. Geografický časopis 53(3), 231-246. (in Slovak with English summary).

Jacobson, D. (2006): Behavioral geography. In: Warf, B. (ed.), Encyclopedia of Human Geography, 17-18. London: SAGE Publications.
Jesse, N. G., Williams, K. P. (2011): Ethnic Conflict: a systematic approach to case of conflict. Washington DC: CQ Press, a division of SAGE.

Kaplan, R. (1994): Balkan ghosts: journey through history. New York: Vintage Departures.

Kleinepier, T., De Valk, H., A. G., Van Gaalen, R. (2015): Life Paths of Migrants: A Sequence Analysis of Polish Migrants' Family Life Trajectories. European Journal of Population 31(2), 155-179, https://doi.org/10.1007 /s10680-015-9345-1.

Kwan, M.-P. (2004): GIS methods in time-geographic research, Geografiska Annaler: Series B, Human Geography 86(4), 267-280, https://doi.org/10.1111 /j.0435-3684.2004.00167.x.

Lambourne, W. (2004): Post-conflict peacebuilding: Meeting human needs for justice and reconciliation. Peace, Conflict and Development 4, 1-24, https:// doi.org/10.7246/pcd.0404.

Lenntorp B. (1999): Time-geography - at the end of its beginning, GeoJournal 48(3), 155-158, https://doi.org /10.1023/A:1007067322523.

Lisica, D. (2013): Norwegian People's Aid, Bosnia and Herzegovina 1993-2013. History of Norwegian People's Aid in Bosnia and Herzegovina. http://www.npa-bosnia .org/1_pdf/history-npa-bih-english.pdf (20 January 2019).

Ljuboja, D. (2015): Migration Processes in the Balkans in the 20th and 21st Centuries. Belgrade. Center for International Relations and Sustainable Development, http://www.cirsd.org/en/young-contributors /migration-processes-in-the-balkans-in-the-20th-and -21st-centuries (23 January 2018).

Lundén, T. (2003): States, Networks and Individual Life Paths. In: Clark, E., Hallin, P. O., Widgren, M. (eds.), Tidrumsfragment: en vänbok till Bo Lenntorp, 137-159. Stockholm \& Lund: Institutionen för kulturgeografi och ekonomisk geografi, Lunds universitet.

Ministry for Human Rights and Refugees of Bosnia and Herzegovina, Department for Housing Policy and Analytical Planning. (2006): Housing and Urban Profile of Bosnia and Herzegovina, An Outline of Devastations, Recovery and Development Perspectives. Sarajevo, http://www.mhrr.gov.ba/PDF/default.aspx?id=243 \&langTag=bs-BA (18 January 2019).

Miller, H. J. (2017): Time Geography and Space-Time Prism. In: D. Richardson, N. Castree, M. F. Goodchild, A. Kobayashi, W. Liu and R. A. Marston (eds.), The International Encyclopedia of Geography. John Wiley and Sons, https://doi.org/10.1002/9781118786352 .wbieg0431.

O’Loughlin, J. (2009): Postconflict Geographies. In: Kitchin, R., Thrift, N. (Eds.), International Encyclopedia of Human Geography 8, 334-338. Amsterdam and Oxford: Elsevier, https://doi.org/10.1016/B978 -008044910-4.00797-5.

Pred, A. (2005): Hägerstrand matters: life(-path) and death matters - some touching remarks. Progress in Human Geography 29, 328-332, https://doi.org/10.1177 /030913250502900310.

Republika Srpska, Institute of Statistics. (2017): Popis stanovništva, domaćinstava i stanova u Republici Srpskoj 2013. godine, http://www2.rzs.rs.ba/static/uploads /bilteni/popis/gradovi_opstine_naseljena_mjesta 
/Rezultati_Popisa_2013_Gradovi_Opstine_Naseljena _Mjesta_WEB.pdf.

Rochovská, A., Káčerová, M., Ondoš, S. (2014): Výskumné metódy v humánnej geografii a ich aplikácie, Vysokoškolská učebnica. Bratislava: Univerzita Komenského v Bratislave.

Sekulić, D., Hodson, R., Massey, G. (2002): War and Tolerance. Revija za sociologiju 33(1-2), 33-57.

Schwanen, T. (2009): Time-space diaries. In: Kitchin, R., Thrift, N. (eds.), International Encyclopedia of Human Geography 11, 294-300. Amsterdam and Oxford: Elsevier, https://doi.org/10.1016/B978 -008044910-4.00547-2.

Schwanen, T., Kwan, M.-P. (2012): Critical space-time geographies thinking the spatiotemporal. Environment and Planning A 44(9), 2043-2048, https://doi.org /10.1068/a45437.

Tariq, S., Woodman, J. (2013): Using mixed methods in health research. Journal of the Royal Society of Medicine. Short Reports 4(6), 1-8, https://doi.org /10.1177/2042533313479197.
Tabeau, E., Bijak, J. (2003): Casualties of the1900s War in Bosnia and Herzegovina: A Critique of Previous Estimates and Latest Results. Paper presented at: The Seminar on the Demography of Conflict and Violence Jevnaker, Norway, 8 to 11 November 2003.

Tabeau, E., Bijak, J. (2005): War-related Deaths in the 1992-1995 Armed Conflicts in Bosnia and Herzegovina: A Critique of Previous Estimates and Recent Results. European Journal of Population 21(2-3), 187-215, https://doi.org/10.1007/s10680-005-6852-5.

Uher, A. (2018): Human behaviour in the territory affected by war conflict: theoretical-methodological notes and examples of war and post war life courses. Montenegrin Journal for Social Sciences 2(2), 109-121

Uher, A., Ira, V. (2019): Life-paths of Serbs in the context of conflicts in former Yugoslavia. Folia Geographica 61(2), 25-44.

Ward, A. R. (2012): Reclaiming Place through Remembrance: Using Oral Histories in Geographic Research. Historical Geography 40, 133-145. http://www.statistika.ba (22 January 2019) http://www.tuzla.ba (15 February 2020) 